\title{
PERBANDINGAN KEJADIAN PENDARAHAN SALURAN CERNA ANTARA PENGGUNAAN ANTIPLATELET TUNGGAL DAN GANDA PADA PASIEN STROKE ISKEMIK AKUT
}

Diterima: 09-03-2018 Disetujui: 18-10-2018

http://dx.doi.org/10.21460/bikdw.v3i2.105

Ni Putu Gita Yanti1, Rizaldy Taslim Pinzon ${ }^{2}$

1Fakultas Farmasi Universitas Sanata Dharma

${ }^{2}$ Fakultas Kedokteran Universitas Kristen Duta Wacana

Korespondensi: gitaynt@gmail.com

\begin{abstract}
ABSTRAK
Pendahuluan: Terapi antiplatelet merupakan terapi yang efektif untuk kejadian stroke iskemik akut, tetapi antiplatelet mempunyai efek samping perdarahan saluran cerna yang dapat meningkatkan angka kematian.

Tujuan: Penelitian ini bertujuan untuk mengukur perbedaan pengunaan antiplatelet tunggal dan ganda pada pasien stroke iskemik akut terhadap kejadian pendarahan saluran cerna di Rumah Sakit Bethesda Yogyakarta selama periode 2015-2017.

Metode: Penelitian ini merupakan penelitian observasional analitik dengan rancangan nested case control dan menggunakan data retrospektif. Data dianalisis dengan analisis deskriptif, analisis bivariat, dan analisis multivariat. Analisis bivariat menggunakan uji Chi-square apabila data yang diperoleh memenuhi syarat atau uji Fisher apabila data yang diperoleh tidak memenuhi syarat serta analisis multivariat jika nilai $\mathrm{p}<0,05$.

Hasil: Pasien dengan pendarahan saluran cerna yang diresepkan antiplatelet ganda sebanyak 44 orang $(27 \%)$ dan tunggal sebanyak 35 orang $(22,2 \%)$. Hasil perbandingan kejadian pendarahan saluran cerna antara antiplatelet tunggal dan antiplatelet ganda tidak berbeda bermakna yaitu dengan nilai $\mathrm{p}>0,05$.

Kesimpulan: Kesimpulan dari penelitian menunjukkan tidak terdapat perbedaan dalam penggunaan antiplatelet tunggal dan ganda terhadap kejadian pendarahan saluran cerna pada pasien stroke iskemik akut di Rumah Sakit Bethesda Yogyakarta.
\end{abstract}

Kata Kunci: stroke iskemik akut, antiplatelet, pendarahan saluran cerna 


\title{
THE COMPARISON OF GASTROINTESTINAL BLEEDING EVENT BETWEEN SINGLE AND DUAL ANTIPLATELET ACUTE ISCHEMIC STROKE PATIENT
}

\author{
Received: 09-03-2018 - Accepted: 18-10-2018 \\ http://dx.doi.org/10.21460/bikdw.v3i2.105
}

\author{
Ni Putu Gita Yanti1, Rizaldy Taslim Pinzon ${ }^{2}$ \\ 1Pharmacy Faculty, Sanata Dharma University \\ ${ }^{2}$ Medical Faculty, Duta Wacana Christian University \\ Corespondence: gitaynt@gmail.com
}

\begin{abstract}
Introduction: Antiplatelet therapy is an effective therapy for the occurrence of acute ischemic stroke, but antiplatelet has a side effect of gastrointestinal bleeding that can increase mortality.

Aims: This study was intended to measure differences between single and dual antiplatelet drug in acute ischemic stroke patients for gastrointestinal bleeding at Bethesda Hospital Yogyakarta during 2015 - 2017 period.

Methods: This was an observational analytic study using nested case control and retrospective data. Data analysis were descriptive, bivariate analysis, and multivariat analysis. Bivariate analysis use Chi-square test if the data obtained qualified or Fisher's exact test if the data obtained are not eligible, with multivariate analysis if the $p$ value $<0,05$.

Results: Among 158 patients with first acute ischemic stroke, 79 patients with gastrointestinal bleeding event and 79 patients is not gastrointestinal bleeding. Patients with gastrointestinal bleeding prescribed dual antiplatelet is 44 people (27\%) and prescribed single antiplatelet is 35 (22.2\%). The result of comparison of gastrointestinal bleeding incidence between single and dual antiplatelet was not significantly different that the $p$ value $>0.05$.

Conclusion: The result showed no difference in the use of single and dual antiplatelet with gastrointestinal bleeding event in acute ischemic stroke patient at Bethesda Hospital Yogyakarta.
\end{abstract}

Keywords: acute ischemic stroke, antiplatelet, gastrointestinal bleeding 


\section{PENDAHULUAN}

Stroke merupakan defisit atau gangguan fungsi sistem saraf yang terjadi mendadak dan disebabkan oleh gangguan peredaran darah otak. Stroke terjadi akibat gangguan pembuluh darah di otak. Gangguan peredaran darah di otak dapat berupa tersumbatnya pembuluh darah di otak atau pecahnya pembuluh darah diotak. Otak yang seharusnya mendapat pasokan oksigen dan zat makanan menjadi terganggu. Kekurangan pasokan oksigen ke otak akan memunculkan kematian sel saraf. ${ }^{1}$

Stroke merupakan salah satu penyebab kecacatan nomor satu di dunia dan penyebab kamatian nomor tiga di USA setelah kardiovaskuler dan kanker. Sekitar duapertiga stroke terjadi di negara-negara berkembang dengan insiden stroke akan meningkat seiring bertambahnya usia. Di Amerika Serikat terdapat sekitar 795.000 orang yang mengalami stroke per tahun, dimana sekitar 610.000 kejadian adalah serangan stroke yang pertama kali, dan sekitar 6,4 juta penduduk Amerika adalah penderita stroke. ${ }^{2,3}$

Stroke merupakan penyebab kematian utama di Indonesia. Jumlah penderita stroke di Indonesia pada tahun 2013 berdasarkan diagnosis tenaga kesehatan (Nakes) diperkirakan sebanyak 1.236 .825 juta jiwa $(7,0 \%)$, sedangkan berdasarkan diagnosis Nakes gejala yang diperkirakan sebanyak 2.137 .941 juta jiwa (12,1\%). Yogyakarta merupakan salah satu dari empat provinsi yang prevalensi penderita strokenya tinggi dan yang menempati urutan pertama ada di Sulawesi Utara $(10,8$ per mil), Yogyakarta (10,3 per mil), Bangka Belitung (9,7 per mil), dan DKI Jakarta $(9,7$ per mil) (Kemenkes RI, 2013). ${ }^{4}$
Angka kejadian stroke di Rumah Sakit Bethesda dari tahun 2011-2015 terus mengalami peningkatan. Stroke iskemik merupakan serangan yang paling sering dijumpai dibandingkan stroke hemoragik di RS Bethesda dengan proporsi stroke iskemik sebesar $76 \%$. Stroke dibagi menjadi 2 katagori yaitu stroke iskemik dan stroke pendarahaan. Sekitar $85 \%$ dari semua kejadian stroke adalah stroke iskemik, tingginya kejadian stroke iskemik maka menyebabkan tingginya juga kejadian stroke iskemik akut. Salah satu terapi yang digunakan untuk merestorasi aliran darah otak dengan menghilangkan sumbatan pada aliran darah menggunakan terapi antiplatelet. 1,5

Terapi antiplatelet efektif untuk mengurangi kejadian stroke, namun antiplatelet mempunyai efek samping pendarahan saluran cerna dan dapat meningkatkan angka kematian. Pada penelitian dengan melibatkan 6.853 pasien stroke iskemik sebanyak 1,5\% menderita pendarahan saluran cerna selama masa perawatan. Mortalitas penderita pendarahan saluran cerna secara bermakna lebih tinggi dibandingkan dengan penderita yang tidak mengalami pendarahan saluran cerna. ${ }^{6}$

Penelitian yang melibatkan 2500 pasien yang berusia 63 tahun dan $63 \%$ pasien merupakan laki-laki. Penelitian ini menggunakan metode randomized clinical trial (RCT). Mortalitas meningkat pada pasien yang mendapatkan antiplatelet ganda yaitu sebesar 77 kematian pada penggunaan aspirin saja 113 kematian (hazard ratio, 1.52; 95\% CI, 1.14 to $2.04 ; \mathrm{p}=0.004)$. Penelitian menggunakan metode potong lintang menggunakan data stroke registry bulan Januari 2011 sampai Desember 2013 dan studi kasus kontrol yang menggunakan data pasien rawat inap di RS Bethesda. 
Penelitian ini melibatkan 1.267 pasien stroke iskemik selama 3 tahun, didapatkan sebesar $4,1 \%$ pasien stroke iskemik mengalami pendarahan saluran cerna. Penggunaan terapi antiplatelet secara bersamaan dengan terapi antikoagulan merupakan faktor risiko yang dapat mempengaruhi pendarahan saluran cerna. 7,8

UK Transient Ischemic Attack study melaporkan bahwa 3,1\% pasien yang mendapatkan terapi antiplatelet mengalami pendarahan saluran cerna. Sebuah penelitian dengan metode randomized, double-blind, placebo controlled melibatkan 5.170 pasien dengan hasil yang menunjukan penggunaan antiplatelet ganda atau kombinasi aspirin dan clopidogrel meningkatkan kejadian pendarahan dibandingkan dengan kelompok yang menggunakan aspirin. Hasil yang berbeda-beda inilah yang melatarbelakangi penelitian dengan tujuan untuk mengukur perbedaan pengunaan antiplatelet tunggal dan ganda pada pasien stroke iskemik akut terhadapat kejadian pendarahan saluran cerna. ${ }^{9}$

\section{METODE}

Desain penelitian yang digunakan adalah observasional analitik dengan rancangan Nested Case Control secara retrospektif. Variabel dalam penelitian ini terbagi menjadi tiga yaitu variabel tergantung, bebas, dan pengacau. Variabel bebas yaitu obat antiplatelet aspirin, clopidogrel dan aspirin plus clopidogrel. Variabel tergantung yaitu kejadian pendarahan saluran cerna. Variabel pengacau terkendali yaitu komorbiditas, konsumsi obat lain yang dapat meningkatkan pendarahan saluran cerna. Variabel pengacau tak terkendali yaitu gaya hidup.

Subjek penelitiannya adalah pasien laki-laki atau perempuan yang terdiagnosis stroke iskemik akut serangan pertama yang mengalami pendarahan saluran cerna (untuk kasus) atau tidak mengalami pendarahan saluran cerna (untuk kontrol). Pasien yang berusia $\geq 18$ tahun yang menjalani pengobatan rawat inap di Rumah Sakit Bethesda Yogyakarta selama periode 2014 hingga 2017 yang memenuhi kriteria inklusi yang telah ditetapkan. Subjek memenuhi kriteria inklusi mendapatkan terapi antiplatelet yaitu aspirin tunggal atau clopidogrel tunggal atau kombinasi aspirin plus clopidogrel. Pasien yang ada pada rekam medis terdapat pendarahan saluran cerna. Kriteria ekslusinya yaitu pasien dengan data rekam medis tidak lengkap.

Pengambilan data dilakukan dari bulan Oktober sampai November 2017. Teknik pengambilan sampel secara consecutive sampling yaitu pemilihan sampel berdasarkan kriteria yang telah ditentukan. Perhitungan besar sampel minimal software Openepi Sample Size Calculators dan didapatkan 79 sampel minimal untuk setiap kelompok. Subjek penelitian yang memenuhi kriteria inklusi 158 kelompok yang mengalami pendarahan saluran cerna 79 orang dan kelompok yang tidak mengalami pendarahan saluran cerna 79 orang.

Pengambilan data dilakukan di Rumah Sakit Bethesda Yogyakarta dengan menggunakan sistem komputerisasi dan melihat rekam medis. Responden yang diambil adalah responden yang masuk dalam kriteria inklusi yang telah ditentukan. Data yang didapat ditulis dalam instrumen penelitian dan kemudian dilakukan pengolahan serta analisis data menggunakan Softwere SPSS (Statistical Package for Social Science) versi 22. Data dianalisis dengan analisis univariat, bivariat serta multivariat. Analisis bivariat menggunakan uji Chi-square 
apabila data yang diperoleh memenuhi syarat atau uji Fisher apabila data yang diperoleh tidak memenuhi syarat. Syarat uji ChiSquare adalah bila tidak ada sel yang mempunyai nilai expected kurang dari lima dengan tabel $2 \times 2$ atau $2 x K$. Uji komparatif numerik tidak berpasangan menggunakan dua uji yaitu uji $t$ tidak berpasangan $\mathrm{Uji} t$ tidak berpasangan digunakan untuk membandingkan rata-rata usia terhadap pendarahan saluran cerna. Analisis bivariat yang mempunyai nilai $p<0,05$ dilakukan analisis multivariat dengan regresi logistik.

\section{HASIL DAN PEMBAHASAN}

Karakteristik subjek penelitian dikelompokkan berdasarkan usia, jenis kelamin, obat antiplatelet, penurunan kesadaran, faktor resiko, dan obat lain yang mempengaruhi pendarahan saluran cerna. Dari 4.211 pasien stroke iskemik selama tahun 2014 sampai 2017 didapatkan 79 orang yang mengalami pendarahan saluran cerna yaitu 1,8 $\%$. Pada penelitian ini digunakan subjek sebanyak 158 pasien stroke iskemik akut dengan jumlah masingmasing kelompok yang diresepkan antiplatelet tunggal sebanyak 72 pasien dan kelompok yang diresepkan antiplatelet ganda sebanyak 86 pasien. Pendarahan saluran cerna yang digunakan yaitu pendarahan saluran cerna yang terjadi selama masa perawatan di Rumah Sakit. Dosis aspirin yang digunakan yaitu 80-100mg dan dosis clopidogrel yang digunakan $75 \mathrm{mg}$. Dari kelompok kasus dan kontrol mayoritas mengalami hipertensi.

Tabel 1. Karakteristik Subjek Penelitian pada kelompok kasus $(n=79)$ dan kontrol (n=79) di RS Bethesda Yogyakarta

\begin{tabular}{|c|c|c|c|c|c|}
\hline \multicolumn{2}{|c|}{ Karakteristik } & \multicolumn{2}{|c|}{ Kasus (n=79) } & \multicolumn{2}{|c|}{ Kontrol (n=79) } \\
\hline & & $\mathbf{n}$ & $\%$ & $\mathbf{n}$ & $\%$ \\
\hline \multirow[t]{5}{*}{ Usia } & $>70$ tahun & 21 & 13,3 & 25 & 15,8 \\
\hline & 61-70 tahun & 29 & 18,4 & 26 & 16,5 \\
\hline & 51-60 tahun & 19 & 12,0 & 23 & 14,6 \\
\hline & 40-50 tahun & 8 & 5,1 & 5 & 3,2 \\
\hline & $<40$ tahun & 2 & 1,3 & 0 & 0,0 \\
\hline \multirow[t]{2}{*}{ Jenis Kelamin } & Laki-laki & 49 & 31,0 & 39 & 24,7 \\
\hline & Perempuan & 30 & 19,0 & 40 & 25,3 \\
\hline \multirow[t]{2}{*}{ Obat Antiplatelet } & Tunggal & 35 & 22,2 & 37 & 23,4 \\
\hline & Ganda & 44 & 27,8 & 42 & 26,6 \\
\hline Penurunan & Ya & 65 & 41,1 & 18 & 11,4 \\
\hline Kesadaran & Tidak & 14 & 8,9 & 61 & 38,6 \\
\hline \multirow[t]{2}{*}{ Komorbid Hipertensi } & $\mathrm{Ya}$ & 44 & 27,8 & 56 & 35,4 \\
\hline & Tidak & 35 & 22,2 & 23 & 14,6 \\
\hline \multirow[t]{2}{*}{ Komorbid DM } & $\mathrm{Ya}$ & 17 & 10,8 & 20 & 12,7 \\
\hline & Tidak & 62 & 39,2 & 59 & 37,3 \\
\hline \multirow[t]{2}{*}{ Komorbid Dislipidemia } & $\mathrm{Ya}$ & 21 & 13,3 & 30 & 19,0 \\
\hline & Tidak & 58 & 36,7 & 49 & 31,0 \\
\hline Penggunaan & $\mathrm{Ya}$ & 12 & 7,6 & 8 & 5,1 \\
\hline bersama NSAID & Tidak & 67 & 42,4 & 71 & 44,9 \\
\hline Penggunaan bersama & Ya Tidak & 4 & 2,5 & 4 & 2,5 \\
\hline Kortikosteroid & & 75 & 47,5 & 75 & 47,5 \\
\hline Penggunaan & Ya Tidak & 22 & 13,9 & 10 & 6,3 \\
\hline bersama Antikoagulan & & 57 & 36,1 & 69 & 43,7 \\
\hline
\end{tabular}


Data pada Tabel 1. menunjukan karakteristik subjek penelitian pasien stroke iskemik baik sebagai kasus maupun kontrol di RS Bethesda Yogyakarta. tahun. Usia terbanyak mengalami stroke iskemik akut dengan pendarahan saluran cerna yaitu pada usia 61-70 tahun. Pendarahan saluran cerna sebagai faktor prognosis pada pasien stroke iskmik periode 2011-2015 adalah pasien stroke iskemik yang mengalami pendarahan terbanyak pada usia $>70$ tahun. Penelitian lain juga menunjukkan hasil yang sama yaitu distribusi pasien stroke iskemik dengan pendarahan saluran cerna terbanyak pada usia 61-70 tahun sebanyak 21 orang $(35,0 \%) .8,10$

Hasil karakteristik subyek penelitian berdasarkan jenis kelamin menunjukkan bahwa pasien stroke iskemik dengan pendarahan saluran cerna paling banyak terjadi pada lakilaki dibandingkan perempuan yaitu sebesar 49 orang (31\%). Risk score to predict gastrointestinal bleeding after acute ischemic stroke, pasien dengan jenis kelamin laki-laki lebih dominan mengalami pendarahan saluran cerna yaitu sebesar 62\%. Pasien stroke iskemik akut dengan pendarahan saluran cerna yang diresepkan obat antiplatelet ganda sebanyak 44 orang $(27,8 \%)$ dan antiplatelet tunggal sebanyak 35 orang $(22,2 \%)$. Pasien stroke yang menerima terapi antiplatelet ganda yaitu sebanyak 2584 orang $(8,2 \%) .9,11$
Pada pasien stroke iskemik akut dengan pendarahan saluran cerna terjadi penurunan kesadaran sebanyak 65 orang $(41,1 \%)$ yang dilihat dari nilai GCS (Glasgow Coma Scale) < 15. Penelitian analisis bivariat menggunakan 147 pasien stroke iskemik dengan pendarahan saluran cerna menyakatakan bahwa terdapat perbedaan yang signifikan antara tingkat kesadaran dengan luaran klinis pasien pasien stroke iskemik akut yang diukur menggunakan skor. ${ }^{10}$

Karakteristik pasien stroke iskemik akut dengan pendarahan saluran cerna berdasarkan komorbiditas yang paling tinggi adalah hipertensi sebanyak 44 orang $(27,8 \%)$. Hipertensi merupakan faktor resiko terbanyak pada pasien stroke iskemik akut yang mengalami pendarahan saluran cerna sebanyak 68 pasien sebesar 78 pasien $(76,4 \%) .8,12$

Karakteristik pasien stroke iskemik akut dengan pendarahan saluran cerna berdasarkan penggunaan obat lain yang dapat mempengaruhi pendarahan saluran cerna paling tinggi adalah pada penggunaan bersama antikoagulan sebanyak 22 orang (13, 9\%). Pemberian antiplatelet bersama antikoagulan meningkatkan kejadian pendarahan saluran cerna sebesar 2$3 \% .13$

Tabel 2. Faktor Risiko yang mempengaruhi pendarahan saluran cerna di RS Bethesda Yogyakarta

\begin{tabular}{lccccccc}
\hline \multirow{2}{*}{ Karakteristik } & \multicolumn{2}{c}{ Kasus } & \multicolumn{2}{c}{ Kontrol } & \multirow{2}{*}{ OR } & \multirow{2}{*}{ IK 95\% } & \multirow{2}{*}{$\boldsymbol{p}$} \\
\cline { 2 - 5 } & $\mathbf{n}$ & $\mathbf{\%}$ & $\mathbf{n}$ & $\mathbf{\%}$ & & & \\
Jenis Kelamin & & & & & & & \\
$\quad$ - Ya & 49 & 31,0 & 39 & 24,7 & 1,675 & $0,889-$ & 0,109 \\
- Tidak & 30 & 19,0 & 40 & 25,3 & & 3,156 & \\
Obat Antiplatelet & & & & & & & \\
$\quad$ - Tunggal & 35 & 22,2 & 37 & 23,4 & 0,903 & $0,483-$ & 0,749 \\
- Ganda & 44 & 27,8 & 42 & 26,6 & & 1,689 &
\end{tabular}




\begin{tabular}{|c|c|c|c|c|c|c|c|}
\hline \multirow{2}{*}{ Karakteristik } & \multicolumn{2}{|c|}{ Kasus } & \multicolumn{2}{|c|}{ Kontrol } & \multirow{2}{*}{ OR } & \multirow{2}{*}{ IK 95\% } & \multirow{2}{*}{$\boldsymbol{p}$} \\
\hline & $\mathbf{n}$ & $\%$ & $\mathbf{n}$ & $\%$ & & & \\
\hline \multicolumn{8}{|c|}{ Penurunan Kesadaran } \\
\hline - $\mathrm{Ya}$ & 65 & 41,1 & 18 & 11,4 & 15,73 & 7,206- & \multirow{2}{*}{$<0,001$} \\
\hline - Tidak & 14 & 8,9 & 61 & 38,6 & 4 & 34,356 & \\
\hline \multicolumn{8}{|c|}{ Komorbid Hipertensi } \\
\hline - $\mathrm{Ya}$ & 44 & 27,8 & 56 & 35,4 & 0,516 & $0,267-$ & \multirow{2}{*}{0,048} \\
\hline - Tidak & 35 & 22,2 & 23 & 14,6 & & 0,997 & \\
\hline \multicolumn{8}{|l|}{ Komorbid DM } \\
\hline - Ya & 17 & 10,8 & 20 & 12,7 & 0,809 & $0,387-$ & \multirow{2}{*}{0,573} \\
\hline - Tidak & 62 & 39,2 & 59 & 37,3 & & 1,692 & \\
\hline \multicolumn{8}{|c|}{ Komorbid Dislipidemia } \\
\hline - Ya & 21 & 13,3 & 30 & 19,0 & 0,591 & $0,301-$ & \multirow{2}{*}{0,126} \\
\hline - Tidak & 58 & 36,7 & 49 & 31,0 & & 1,161 & \\
\hline \multicolumn{8}{|c|}{ Penggunaan bersama NSAID } \\
\hline - Ya & 12 & 7,6 & 8 & 5,1 & 1,590 & $0,612-$ & \multirow{2}{*}{0,339} \\
\hline - Tidak & 67 & 42,4 & 71 & 44,9 & & 4,130 & \\
\hline \multicolumn{8}{|c|}{ Penggunaan bersama Kortikosteroid } \\
\hline - Ya & 4 & 2,5 & 4 & 2,5 & 1,000 & $0,241-$ & \multirow{2}{*}{$1,000^{*}$} \\
\hline - Tidak & 75 & 47,5 & 75 & 47,5 & & 4,147 & \\
\hline \multicolumn{8}{|c|}{ Penggunaan bersama Antikoagulan } \\
\hline - Ya & 22 & 13,9 & 10 & 6,3 & 2,663 & $1,166-$ & \\
\hline - Tidak & 57 & 36,1 & 69 & 43,7 & & 6,081 & 0,018 \\
\hline
\end{tabular}

*Uji Fisher

Pengaruh dari usia, jenis kelamin, obat antiplatelet, penurunan kesadaran, komorbiditas serta penggunaan bersama obat lain yang mempengaruhi pendarahan saluran cerna dapat dilihat di tabel 2. Pendarahan saluran cerna ini terjadi karena permeabilitas gastrointestinal meningkat serta disfungsi barrier gastrointestinal yang memicu terjadinya stress ulcer disebabkan oleh Corticotrophin Releasing Hormone (CRH) pada hipotalamus yang meningkat ketika terjadinya infark serebral. ${ }^{14}$

Hasil analisis bivariat bahwa jenis kelamin, usia, dan obat antiplatelet (tunggal dan ganda) mempunyai nilai $p>0,05$ yang berarti tidak memiliki hubungan yang bermakna antara kedua variabel. Penelitian ini menunjukkan bahwa penggunaan antiplatelet ganda (kombinasi asirpin plus clopidogrel) dibandingkan dengan antiplatelet tunggal (aspirin) memiliki nilai
$\mathrm{OR}=0,903 \quad(\mathrm{IK} \quad 95 \% \quad 0,483-1,689)$. Penelitian dengan melibatkan 5.170 pasien melaporkan bahwa 3,1\% pasien yang mendapatkan terapi antiplatelet mengalami pendarahan saluran cerna pendarahan pada pasien yang menggunakan kombinasi aspirin dan clopidogrel sebanyak 7 $(0,3 \%)$ pasien dan pada kelompok yang menggunakanaspirin sebanyak $8(0,3 \%)$ orang. Kesimpulan dari penelitian ini adalah penggunaan antiplatelet ganda atau kombinasi aspirin dan clopidogrel tidak meningkatkan kejadian pendarahan dibandingakan dengan kelompok yang menggunakan aspirin tunggal. ${ }^{9}$

Pada penelitian ini menunjukkan bahwa pemakaian antiplatelet ganda tidak meningkat-kan kejadian perdarahan saluran cerna dibanding antiplatelet tunggal pada pasien stroke iskemik akut di RS Bethesda Yogyakarta. Penyebabnya kemungkinan karena peneliti hanya menggunakan subyek dari data 
rekam medis pasien rawat inap yang mengalami pendarahan saluran cerna. Hal ini juga kemungkinan disebabkan oleh penggunaan antiplatelet jangka pendek (selama rawat inap saja), seharusnya efek samping pendarahan saluran cerna pada penggunaan antiplatelet timbul akibat dari penggunaan jangka panjang. Untuk bisa melihat penggunaan antiplatelet mempengaruhi pendarahan saluran cerna seharusnya penggunaan antiplatelet dipantau pada pasien saat keluar dari RS atau pada penggunaan di rumah. Penggunaan aspirin jangka panjang secara signifikan mempengaruhi pendarahan saluran cerna bagian atas dengan nilai $p=0,004.15$

Hasil penelitian pengaruh penurunan kesadaran terhadap pendarahan saluran cerna memiliki hubungan yang bermakna dengan nilai $p<0,001$. Tidak terdapat hubungan yang signifikan antara GCS score dengan pendarahan salura cerna, nilai $p<0,105 \quad \mathrm{OR}=1,45$ (IK $95 \% 0,73-27,3) .16$

Hasil analisis pengaruh komorbiditas terhadap pendarahan saluran cerna menghasilkan nilai $p>0,05$ untuk dislipidemia, diabetes mellitus, yang menunjukkan tidak ada hubungan sedangkan komorbiditas yang memiliki hubungan dengan pendarahan saluran cerna yaitu hipertensi dengan nilai $p=0,048$ $\mathrm{OR}=0,516$ (IK 95\% 0,267-0,997). Faktor resiko hipertensi tidak memiliki hubungan yang bermakna dengan pendarahan saluran cerna, nilai $p=0,600.12$

Hasil analisis pengaruh obat lain yang digunakan terhadap pendarahan saluran cerna menghasilkan nilai $p>0,05$ untuk penggunaan NSAID dan kortikosteroid hal ini menunjukan tidak ada pengaruh dari obat NSAID dan kortikosteroid. NSAID mempunyai hubungan signifikan terhadap pendarahan saluran cerna. NSAID menghambat COX-1 dan COX-2 dimana dapat menginduksi terjadinya ulcer. Penghambatan COX-1 dimana COX-1 berfungsi sebagai produksi prostagladi. Prostagladin berfungsi sebagai pertahanan mukosa lambung, sehingga menyebabkan terjadinya tukak lambung yang memicu terjadinya pendarahan saluran cerna. Pada penelitian ini NSAID tidak mempunyai pengaruh terhadap pendarahan saluran cerna kemungkinan karena penggunaan NSAID jangka pendek. Penggunaan NSAID jangka panjang menyebabkan iritasi lokal mukasa lambung menjadi lebih lama dan hebat. Mekanisme kortikosteroid mempengaruhi pendarahan saluran cerna karena kortikosteroid menginduksi ulcer dan pendarahan saluran cerna dimana ulcer terbentuk akibat penghambatan sintesis prostaglagin pada phospholipase A. ${ }^{17,18,19}$

Hasil analisis bivariat pada penggunaan bersama Antikoagulan memiliki hubungan yang bermakna terhadap kejadian pendarahan saluran cerna dengan nilai $p<0,018$. Penggunaan antiplatelet bersama antikoagulan meningkatkan kejadian pendarahan saluran cerna yang dapat memperburuk luaran klinis pasien. Obat antikoagulan juga memiliki efek samping pendarahan saluran cerna. Mekanisme obat antiplatelet plus antikoagulan menyebabkan peningkatan pendarahan yaitu obat antiplatelet yang membuat ulcer dan erosi pada saluran cerna dan obat antikoagulan yang memicu pendarahan dari lesi yang ada. ${ }^{13,20}$ 
Tabel 3. Hasil analisis multivariat regresi logistik

\begin{tabular}{lccc}
\hline \multicolumn{1}{c}{ Karakteristik } & OR & IK 95\% & Nilai $\boldsymbol{p}$ \\
\hline Penurunan Kesadaran & 20,742 & $8,305-51,806$ & $<0,001$ \\
Komorbid Hipertensi & 0,418 & $0,171-1,025$ & 0,057 \\
Penggunaan Bersama Antikoagulan & 1,981 & $0,639-6,145$ & 0,236 \\
\hline
\end{tabular}

Hasil data analisis bivariat yang nilai $\mathrm{p}<0,005$ dilakukan analisis multivariat. Hasil analisis multivariat menunjukan bahwa penurunan kesadaran meningkatkan resiko pendarahan saluran cerna dengan nilai $\mathrm{p}<0,001$ OR $=20,742$ (IK 95\% 0,171-1,025). Hasil ini sama dengan penelitian Ruijun et al. (2014) yang menggunakan data dari China National Stroke Registry menyatakan bahwa penurunan kesadaran (yang dilihat dari penurunan GCS sebanyak 1 poin) mempengaruhi pendarahan saluran cerna pada pasien stroke iskemik akut dengan nilai $\mathrm{p}=0,01$ $\mathrm{OR}=1,06 \quad$ (IK $\quad 95 \% \quad 1,01-1,11)$. Penurunan kesadaran meningkatkan resiko pendarahan saluran cerna karena hampir semua pasien pendarahan saluran cerna mengalami anoreksia dan penurunan status gizi sehingga akan mempengaruhi kadar protein di dalam darah yang menyebabkan tubuh kekurangan asam amino esensial untuk mensintesis berbagai macam zat dan hormone. ${ }^{21}$

Hasil analsis multivariat (tabel 3) menunjukan bahwa hipertensi tidak memiliki hubungan yang signifikan dengan pendarahan saluran cerna dengan nilai $\mathrm{p}<0,057$ $\mathrm{OR}=0,418 \quad$ (IK 95\% 0,171-1,025). Penelitian yang menggunakan 6,529 pasien stroke iskemik yang mengalami hipertensi dengan pendarahan saluran cerna berdasarkan analisis multivariat dinyatakan bahwa tidak memiliki hubungan yang signifikan antara hipertensi dengan pendarahan saluran cerna. Pada penelitian ini juga menunjukan bahwa penggunaan obat bersama antikoagulan tidak memiliki hubungan yang signifikan dengan pendarahan saluran cerna yang dianalisis menggunakan analisis multivariat dengan nilai $p=0,236$. Penggunaan antiplatelet dengan antikoagulan tidak memiliki hubungan yang signifikan dengan nilai $p=0,886.10,12$ Keterbatasan dalam penelitian ini adalah peneliti hanya melihat kejadian pendarahan saluran cerna selama rawat inap saja. Pada penggunaan antiplatelet jangka panjang yang dapat menyebabkan pendarahan saluran cerna, seharusnya dilakukan pemantauan setelah pasien keluar dari rumah sakit atau saat sudah dirumah untuk melihat kejadian pendarahan dengan durasi penggunaan antiplatelet yang lebih lama.

\section{KESIMPULAN}

Tidak ada perbedaan dalam penggunaan antiplatelet tunggal dan ganda terhadap kejadian pendarahan saluran cerna pada pasien stroke iskemik akut di Rumah Sakit Bethesda Yogyakarta.

\section{DAFTAR PUSTAKA}

1. Pinzon, R.T., Adnyana, K.S.G., Sanyasi, R.D.L.R., Profil Epidemiologi Stroke: Gambaran Tentang Pola Demografi, Faktor Resiko, Gejala Klinik, dan Luaran Klinis Pasien Stroke. 2016.

2. Sutrisno, A., Stroke? you must know before you get it. 2007.

3. Goldstein, L.B. et al.,x. Guidelines for primary prevention of stroke: a guideline for healthcare professionals from the American Heart Association. Stroke. 42, 517. 2011.

4. Riskesdas. Riset Kesehatan Dasar: Badan Penelitian dan 
Pengembangan Kesehatan Kementrian Kesehatan RI. 2013.

5. Gofir, A. Manajemen Stroke Evidence Based Medicine. 2009.

6. Ng, Y.S., Stein, J., Ning, M.M., Schaeffer, R.M. Comparison of Clinical Characteristics And Functional Outcomes of Ischemic Stroke in Different Vascular Territories. Stroke, 38:23092314. 2007.

7. The SPS3 Investigators. Effects of klopidogrel added to aspirin in patient with recent lacunar stroke. New England Journal of Medicine, 367, 817- 825. 2012.

8. Susanti, M.E., Pinzon, R., Sugiyanto. Evaluasi Penggunaan Obat Antiplatelet Terhadap Kejadian Pendarahan Saluran Cerna Beserta Faktor Resikonya Pada Pasien Stroke. Fakultas Farmasi Universitas Gadjah Mada. 2014.

9. Wang, Y., Wang, Y., Zhao, X., Liu, L., Wang, D., Wang, C., et al.. Clopidogrel with Aspirin in Acute Minor Stroke or Transient Ischemic Attack. New England Journal of Medicine, 369, 11-19. 2013.

10. Debora, R.S., Pinzon, R.T., Pramuditas, E.A. Pendarahan Saluran Cerna Sebagai Faktor Prognosis pada Pasien Stroke Iskemik Akut. Fakultas Kedokteran Universitas Kristen Duta Wacana. 2016.

11. Ruijun, Ji., Shen, H., Pan, Y., et al. Risk Score to Predict Gastrointestinal Bleeding After Acute Ischemic Stroke. BMC Gastroenterology, 14, 130. 2014.

12. Ogata, T., Kamouchi, M., Mutshuo, R., et al. Gastrointestinal Bleeding in Acute Ischemic Stroke: Recent Trends from the Fukuoka Stroke Registry. Cerebrovascular Disease, 4, 156-164. 2014.

13. Pipilish, A., Makrygiannis, S., Chrisanthopoulou, E., et al.
Gastrointestinal Bleeding in Patients Receiving Antiplatelet and Anticoagulant Therapy: Practical Guidance for Restarting Therapy and Avoiding Recurrences. Hellenic J Cardiol, 55, 499-509. 2014.

14. Liu, Y. Qi, Z., Guo, S., Wang, Z., Yu, X., Ma, S. Role of Corticotrophin Releasing Hormone in Cerebral InfarctionRelated Gastrointestinal Barrier Dysfunction. World J Emerg Med, 2(1), 59-65. 2011.

15. Huang, S.E., Strate, L.L., Wendy, W. Long Term Use of Aspirin and the Risk of Gastrointestinal Bleeding. Am J Med, 124(5), 426433. 2011.

16. Hamidon, BB., and Raymond, AA. The risk factors of gastrointestinal bleeding in acute ischemic stroke. Med J Malaysia, 61(3), 288-291. 2006.

17. Waranugraha., Y., Suryana, B.P., Pratomo, B. Hubungan Pola Penggunaan OAINS dengan Gejala Klinis Gastropati pada Pasien Reumatik. Jurnal Kedokteran Brawijaya, 26(2), 107-111. 2010.

18. Dowling, P. Corticosteroid $\& \quad$ Nonsteroidal Antiinflammatory Drug Interaction. NAVC Clinician's Brief, 89. 2011.

19. Wallace, J.L., and Linda, V. NSAID-induced gastrointestinal damage and the design of GIsparing NSAIDs. Current Opinion in Investigational Drugs, 9(11), 1151-1156. 2008.

20. Barada, K., et al. Gastrointestinal Bleeding in the setting of Anticoagulation and Antiplatelet Therapy. $J$ clin Gastroenterol, 43(1), 5. 2009.

21. Faridah, V.N., dan Farida. Penatalaksanaan pendarahan saluran cerna bagian atas dengan nutrisi enteral dini terhadap kadar albumin. Jurnal Gizi Klinik Indonesia, 13(4), 188-195). 2017. 